This is a postprint of an article published in

Wagner-Döbler, I., Biebl, $\mathbf{H}$.

Environmental biology of the marine Roseobacter lineage

(2006) Annual Review of Microbiology, 60, pp. 255-280. 


\title{
Environmental Biology
}

\section{of the marine Roseobacter lineage}

\author{
Irene Wagner-Döbler ${ }^{1)} \&$ Hanno Biebl \\ National Research Institute for Biotechnology $(G B F)$, Department for Cell Biology
}

Germany

Running title: Roseobacter ecology

Key words: Alphaproteobacteria, abundance, ecological niche, carbon cycle, sulfur cycle, dinoflagellates, quorum sensing, gene transfer, evolution

1) corresponding author. GBF, Mascheroder Weg 1, 38124 Braunschweig, Germany.

Email iwd@gbf.de, phone +49 5316181 406; fax +49 5316181978 


\section{ABSTRACT}

The Roseobacter lineage is a phylogenetically coherent, physiologically heterogeneous group of Alphaproteobacteria comprising up to $25 \%$ of marine microbial communities, especially in coastal and polar oceans, and it is the only one where cultivated bacteria are closely related to environmental clones. Currently 41 subclusters are described, covering all major marine ecological niches (seawater, algal blooms, microbial mats, sediments, sea ice, marine invertebrates). Members of the Roseobacter lineage play an important role for the global carbon and sulfur cycle and the climate, since they have the ability for aerobic anoxygenic photosynthesis, oxidise the greenhouse gas carbon monoxide, and produce the climate relevant gas dimethylsulfide through the degradation of algal osmolytes. Production of bioactive metabolites and quorum sensing regulated control of gene expression mediate their success in complex communities. Studies of representative isolates in culture, whole genome sequencing, e.g. of Silicibacter pomeroyi, and the analysis of marine metagenome libraries have started to reveal the environmental biology of this important marine group. 


\section{INTRODUCTION}

The microbial ecology of the world's oceans is one of the most fascinating chapters in microbial ecology. It was here where surveys of phylogenetic marker genes for the first time revealed a hidden world of microbes completely unknown to microbiologists at the time because these organisms had never been cultivated. Using 16S rRNA based methods, global populations were discovered for many of these uncultivated marine clusters which showed clear patterns in time and space, making them ideal subjects to study ecological adaptations and evolution. The huge volume of the oceans, the fact that all biochemical processes in the ocean are crucial for the global cycles of carbon, sulfur, and other elements, and the fact that these cycles are driven by large, worldwide distributed populations of marine microbes which have been subjected to strong selective pressure over very long evolutionary timespans, all make it fundamentally important scientifically and mandatory from an environmental perspective to understand the ecology and physiology of these populations, particularly also in view of environmental threats like global warming and pollution.

The socalled Roseobacter lineage has played a special role from the beginning since it was the only abundant marine group where cultivated strains were available which were relatively closely related to cloned environmental sequences $(18,30,35)$. Thus, interest in this group has been steadily increasing since the description of Roseobacter denitrificans (87), its first representative. This organism has the ability for light driven energy generation using the ancient purple bacterial mechanism of anaerobic photosynthesis without production of oxygen (anaerobic anoxygenic photosynthesis, AnAnP); however, unlike purple bacteria, it is able to do this in the presence of oxygen (under aerobic conditions) and was therefore termed aerobic anoxygenic phototroph (AAnP) $(9,50,113)$. Because the contribution of aerobic anoxygenic photosynthesis to the total energy budget of the cell is small and only seen under ecologically relevant conditions, 
it was originally thought to be a trait of little or no adaptive significance. This perspective changed completely when bacteriochlorophyll a (bchla) was found in the open ocean (56) and was estimated to contribute up to $10 \%$ to photosynthetic energy generation (55).

Today, appr. 1500 16S rRNA gene sequences from the Roseobacter lineage have been deposited in databases (18), making it the most extensively studied abundant marine group. Many new interesting physiological traits have been found in addition to aerobic anoxygenic photosynthesis, e.g. degradation of algal sulphur compounds, carbon monoxide oxidation, degradation of aromatics, reduction of trace metals, symbiotic and pathogenic relationships, production of bioactive secondary metabolites and quorum sensing. Thus, the Roseobacter lineage can now be viewed as a phylogenetically coherent but physiologically diverse group of abundant marine bacteria which inhabit a wide range of niches in the world's oceans, mainly but not exclusively in coastal zones and polar regions, including marine snow, phytoplankton, sea ice, hydrothermal vents, sediments, macroalgae and various invertebrates. The combination of culture independent surveys with work on representative isolates has resulted in a wealth of new and ecologically important findings for this group which will be reviewed below.

\section{ABUNDANCE AND DIVERSITY IN MARINE ENVIRONMENTS}

This topic has recently been covered by Buchan et al. (18) in an exellent review. Their phylogenetic analysis provides a framework on which future work can be based. I will summarize the main points briefly; more details and references can be found there.

\section{Abundance}

The Roseobacter lineage is a group of marine bacteria and cloned environmental sequences with $>89 \%$ identity of the $16 \mathrm{~S}$ rRNA gene, comprising at present 17 genera, 36 described species and 
hundreds of cloned environmental sequences and uncharacterised isolates (18). Roseobacter populations have been found in practically every oceanic habitat investigated, sometimes in very large numbers. Reports on their relative abundance in the world's ocean vary, partly because of differences in methodology (e.g. frequency of Roseobacter isolates among cultivated strains, probe hybridisation using group, genus or subcluster specific probes, frequency of clones in PCR generated clone library, quantitative PCR, most probable number counting coupled to PCR, frequency of 16S rRNA genes in BAC libraries and shotgun clone libraries), partly because of "true" differences between habitats and seasons. However, from the multitude of studies (reviewed in (18)) it emerges that the Roseobacter lineage is one of the most abundant marine lineages which is especially dominant in coastal environments and the polar oceans. For example, in a BAC library close to the coast of Monterey, Silicibacter like sequences represented $21.1 \%$ (0 $\mathrm{m}$ depth) and $23.6 \%(80 \mathrm{~m})$ of all $16 \mathrm{~S}$ rRNA sequences present $(24,103)$, while they accounted for $3 \%$ in the Sargasso Sea shotgun clone library $(69,106)$, datasets which are largely free from PCR bias. The uncultivated Roseobacter subcluster DC5-80-3 accounted for 20\% of all bacteria in the Southern Ocean based on quantitative PCR (86).

\section{Diversity}

Buchan et al. (18) compiled all available 16S rRNA sequence information for Roseobacter organisms from the Ribosomal Database Project II release 9.22, the Sargasso Sea metagenomic library (106), and the Sapelo Island Microbial Observatory 16S rRNA database (http://simo.marsci.uga.edu). From a total number of 1497 sequences longer than $1000 \mathrm{nt}$ they constructed a comprehensive phylogenetic tree for the Roseobacter lineage (Fig. 1). Using a sequence similarity $\geq 99 \%$ as a criterion, 41 lineages became apparent, of which 13 represent major clusters with >10 nonredundant members which are discussed briefly below.

DC5-80-3 is the largest of all clusters, consisting primarily of cloned environmental sequences, and the only one for which the global distribution has been systematically determined (86). 
Members of this group have been detected in surface waters (to $40 \mathrm{~m}$ ) of temperate and polar oceans of both hemispheres, and to depths of $2300 \mathrm{~m}$ and $1000 \mathrm{~m}$ in the Arctic and Southern Oceans, respectively (86). Based on quantitative PCR, they were estimated to comprise $20 \%$ of all bacteria in the Southern Ocean (86), and around 5\% in coastal clone libraries $(39,77)$.

OBULB and SPON are two related clusters which are comprised mainly of cultivated strains ( 70\%). Representatives of OBULB were found in coastal seawater samples, sediments, seagrass, and starfish. SPON isolates were retrieved from the oxic/anoxic interface in the Black Sea, coastal environments, open ocean, deep sea vents and marine sponges.

The OCT cluster has clone (55\%) and isolate (45\%) sequences in similar proportions, almost all of them derived from sea ice or polar environments.

RGALL is well represented by cultivated strains (68\% of all sequences), which were often isolated from eukaryotic marine organisms, e.g. the scallop Pecten maximus, the oyster Ostrea edulis, the fish Scophthalmus maximus, an egg from the squid Loligo pealei, dinoflagellates, and marine phytoplankton.

CHAB-I-5 is the only Roseobacter subcluster which presently contains exclusively cloned environmental sequences, more than half of which are derived from coastal seawater. CHAB-I-5 constitutes $20 \%$ of all 16S rRNA containing clones of a Monterey Bay BAC clone library (23, 103). NAC11-7 is dominated by cloned sequences (88\%), most of them associated with phytoplankton blooms in coastal areas. The two isolates were obtained from coastal seawater on oligotrophic media (91).

RATL and TM1040 are two clusters within the Silicibacter-Ruegeria superlineage, again comprised of both isolates and clones. While RATL sequences are mostly from corals, TM1040 sequences are from coastal seawater or sediment.

Another cluster with a preference for a certain habitat is DG1128, which is well represented by 
sequences from macroalgae and phytoplankton. ANT9093 is a mixed cluster, containg sequences from polar sea ice, sediments, fish, and sponges, while clusters AS-21 and AS-26 are mainly derived from coastal water and sediment.

With the exception of CHAB-15, all clusters contain both cloned environmental sequences and cultivated strains, thus confirming the original observation from the Roseobacter lineage, albeit at a much higher level of phylogenetic resolution. The level of $\geq 99 \%$ sequence similarity of the $16 \mathrm{~S}$ rRNA gene within the clusters is usually regarded as criterion for species identity. However, clusters were neither homogeneous with respect to habitat (sources of clones and isolates) nor physiology (e.g. AAnPs and most other metabolic traits are distributed throughout the tree, see Fig. 1), although trends were sometimes apparent. Thus, a finer phylogenetic resolution is needed to determine evolutionary relationships within the Roseobacter lineage. Methods like multilocus sequence typing of housekeeping genes or whole genome sequence comparisons might be excellent tools for this.

Habitat specific functional genetic islands might be present in the genomes of these bacteria, similar to pathogenicity islands or symbiotic islands (74), which are transferred through lateral gene transfer. The photosynthesis gene cluster, comprising about $45 \mathrm{~kb}$ of genetic information and localized on a linear plasmids in some species (75) could be an example $(3,47,71)$. The combination of habitat specific functional genetic modules in a mosaic way in the various representatives of the Roseobacter lineage might explain their physiological and ecological diversity on the one side and phylogenetic coherence on the other side. Hypotheses like this will be testable by analyses of the upcoming genome sequences of this group. 


\section{AEROBIC ANOXYGENIC PHOTOTROPHY}

\section{Definition}

Light is the one unlimited energy source in the upper layers of the ocean. Oxygenic phototrophic bacteria, i.e. Synechococcus and Prochlorococcus species, are able to grow autotrophically using light and $\mathrm{CO}_{2}$ as sole sources of energy and carbon, respectively. Their important role for the ecology of the oceans and the global fixation of $\mathrm{CO}_{2}$ is well established, and it has been shown that they occur as huge vertically stratified populations which have evolved into genetically distinct ecotypes adapted to the light regime and nutrient conditions of their respective ocean habitat. Recently, two other types of light driven energy generation have been shown to be of major importance in the ocean, namely aerobic anoxygenic photosynthesis (AAnP), and proteorhodopsin based phototrophy. Both are based on membrane bound pigments and accessory proteins, and use light energy to pump protons out of the cell, thus transforming light into an electrochemical potential across the membrane. The resulting proton motive force is in turn used for the synthesis of ATP from ADP (Fig.2). Both AAnP and proteorhodopsin based phototrophy are not directly coupled to the fixation of $\mathrm{CO}_{2}$ (and therefore do not represent "photosynthesis" in the classical sense), but supply additional energy to the cell, reducing the need for respiratory oxidation of organic substrates. The term "aerobic anoxygenic photosynthesis" which literally means "photosynthesis performed in the presence of oxygen (aerobic) without generation of oxygen (anoxygenic)" is misleading, since no light driven synthesis of organic carbon (photosynthesis) is carried out, but will be used in this review because it is established in the scientific literature $(9,50$, 113). While proteorhodopsin has until now not been deteced in Roseobacter bacteria, AAnP is found in many of its representatives and will be discussed below.

\section{Ecological importance}


In 1979, aerobic pink pigmented bacteria containing bacteriochlorophyll a (bchla) were discovered in the sediments of the Japanese bay by Shiba (89) and later described as Erythrobacter (88) and Roseobacter species (87). In the following years, many more bchla containing bacteria were isolated, which occurred in marine, aquatic and terrestrial habitats and even in the depth of the Atlantic ocean in the black smoker waters of the Juan Fuca Ridge (112). Most belonged to the Alphaproteobacteria, but one Betaproteobacterium, Roseateles depolymerans, was also found (102). Table S1 shows a list of currently validly described Proteobacteria containing bchla. However, many more bchla containing organisms, both Alpha- and Betaproteobacteria, remain to be discovered (9). Within the Roseobacter lineage, AAnP is scattered throughout the tree (Fig.1) (3). Presently, it is found in nine of the 41 Roseobacter lineages. Aerobic anoxygenic phototrophs were reviewed by Yurkov, Beatty and coworkes $(6,78,113)$.

Interestingly, it was the search for bchla in the Juan Fuca Ridge using in situ measurements that triggered the discovery of the widespread distribution of bchla in the world oceans (56) and then led to the estimation that bchla containing organisms constituted $10 \%$ or more of total bacterial cells in sea water (55). This value has later been shown by quantification of bchla and the puf LM genes to be about one order of magnitude too high $(33,85)$. However, counts of bchla containing organisms were very diverse, being highest in the Norwegian Sea (2.2\% of all bacteria), in Chesaspeake Bay (10.7 \%) and in Crane Neck, Long Island Sound, New York (18.7\%), while they were around $1 \%$ or less in the open ocean (85), in accordance with the Sargasso Sea shotgun clone library, were only 17 new pufM sequences were found out of 1.2 million genes $(85,106)$. Thus, AAnP bacteria may be especially adapted to conditions arising during algal blooms, coastal pollution or in cold seas.

\section{Anoxygenic photosynthesis}

Anaerobic anoxygenic photosynthesis (AnAnP) is the most ancient form of photosynthesis, only functioning in the absence of oxygen. AnAnP bacteria are able to grow photoautotrophically or 
photoorganotrophically using light as an energy source, reduced inorganic compounds (e.g. $\left.\mathrm{H}_{2} \mathrm{~S}\right)$ for the generation of reducing power $(\mathrm{NAD}(\mathrm{P}) \mathrm{H})$, and $\mathrm{CO}_{2}$ or organic substrates for the synthesis of biomass. Because of the spectacular colors caused by their carotenoids, they are collectively called purple bacteria. They are believed to be the ancestors of the Proteobacteria, and all species isolated so far belong to either the Alpha-, Beta or Gammaproteobacteria. Some are facultative anaerobes, i.e. in the presence of oxygen, photosynthesis is switched off completely and energy is generated from organic substrates by respiratory electron transfer, like in Rhodobacter sphaeroides, which is most closely related to the Roseobacter lineage.

Structure of photosynthetic membrane and cyclic photophosphorylation. Anaerobic anoxygenic photosynthesis is one of the best studied membrane processes and has served as a model to understand the primary electron transfer events during photosynthesis. Energy is generated through a light driven cyclic photosphorphorylation process brought about by membrane bound pigmentprotein complexes which consist of different units, spatially arranged in a highly complex and completely defined fashion to set up the proton motive force:

(1) The socalled reaction center, called P870, with the special pair of bacteriochlorophyll molecules engaged in the primary energy transformation event, and the pufL and pufM proteins which determine its exact stereochemistry;

(2) light harvesting complex 1 (LH1) and

(3) light harvesting complex 2 (LH2), also called antennae complexes, both consisting of bchla, carotenoids and accessory proteins and serving to channel light energy to the reaction center and protect it from oxidative damage;

(4) the cytochrome $b_{1}$ complex, which is shared with the oxidative respiratory electron chain.

An adjacent ATPase membrane complex synthesizes ATP at the expense of proton motive force (Fig. 2). The reaction center P870 has a very low electrochemical potential. Light energy trans- 
forms it into an activated state with a high electrochemical potential. Subsequently electrons flow across a series of electron carriers back to P870, which returns to its original state and is then able to take up new light energy. In the process, ATP is generated through cyclic photophosporylation by the ATPase complex.

Oxygenic photosynthesis: By contrast, oxygenic phototrophs (e.g. cyanobacteria and chloroplasts of green plants) have a two stage, interconnected light reaction using photosystem I (P700) and the preceding photosystem II (P680), which serves to split water into protons and oxygen. Electrons travel from P680 to P700, generating ATP by noncyclic photophosphorylation. However, under anaerobic conditions many algae and some cyanobacteria are able to carry out cyclic photophosphorylation using only photosystem I, thus they photosynthesize anoxygenically like purple bacteria, showing the close evolutionary relationship between oxygenic and anoxygenic photosynthesis.

\section{Aerobic anoxygenic photosynthesis}

Most Roseobacter lineage AAnP bacteria are obligate aerobes, but some (e.g. Roseobacter litoralis (87)and Dinoroseobacter shibae (11)) are able to use nitrate as a terminal electron acceptor and thus are facultative anaerobes. They rely on the respiratory electron chain for energy generation and biomass synthesis, deriving only little additional energy from light driven ATP synthesis. The Calvin cycle, including its key enzyme Rubisco needed for autotrophic $\mathrm{CO}_{2}$ fixation, is not present. Low levels of light induced $\mathrm{CO}_{2}$ fixation which have sometimes been observed are consistent with anaplerotic metabolism common in heterotrophic bacteria $(55,113)$. The photosynthetic gene cluster of Roseobacter denitrificans is highly homologous to the that of Rhodobacter sphaeroides (appr. $45 \mathrm{~kb}$ ). Detailed comparisons have been undertaken between those two organisms which are reviewed by Yurkov \& Beatty (113) and can briefly be summarized as follows:

Pigments: Spheroidenone is the only carotenoid detected in Roseobacter AAnP bacteria so far; it 
is also present in Rhodobacter sp.. Other AAnPs, however, showed a range of different carotenoids (113). Their main function is to protect the cell from oxidative damage. All AAnP bacteria use bacteriochlorophyll a. The synthesis of bchla is completely inhibited even by very low light intensities. The amount of bchla produced in the dark is generally about $10 \%$ or less of that in anaerobic anoxygenic phototrophs, and in some species it depends strongly on nutrient composition, salt concentration, and unknown stress factors $(10,12,101)$. Synthesis of bchla and can even be transiently completely suppressed like in Roseovarius tolerans $(3,58)$. This may indicate that bchla is produced as an adaptive response to specific conditions relevant to the natural habitat of the organisms.

Structure of photosynthetic membranes: No specialised photosynthetic membranes have been found so far in Roseobacter AAnP bacteria, presumably because of the low concentrations of bchla present. The structural diversity of the peripheral antenna complexes is large in AAnP bacteria, and some show unusual light adsorption characteristics. However, the photosynthetic membrane complex itself is virtually indistinguishable between Rhodobacter and Roseobacter.

Functioning of the reaction center. RC complexes were isolated from several AAnP bacteria and their absorption spectra were found to be very similar to those of anaerobic anoxygenic phototrophs and they were shown to be functional in terms of a cyclic electron transfer system (113). No electron transfer occured under anaerobic conditions. It was suggested that the midpoint potential of the quinone $\mathrm{Q}_{\mathrm{A}}$, the primary electron acceptor of the $\mathrm{RC}$, might be too high; therefore this $\mathrm{Q}_{\mathrm{A}}$ is in the reduced state (dihydroquinol) under anaerobic conditions and cannot accept an electron, unless an oxidant such as $\mathrm{O}_{2}$ transforms it to the quinone form which is capable of acting as an electron acceptor.

Regulation. The anoxygenic photosystems of purple bacteria and Roseobacter organisms, which are virtually indistinguishable with respect to structure and functioning, operate in complementary mode without overlap: Low light intensities completely stop bchla synthesis in AAnPs, 
while high light intensities merely inhibit bchla synthesis in AnAnP bacteria. All cyclic electron transport ceases in the presence of oxygen in AnAnPs, and in the absence of oxygen in AAnPs.

In summary, AAnP bacteria have a completely functional photosynthetic machinery of the purple bacterial type which is operated under conditions contrary to those for which is originally evolved. In spite of the detailed knowledge about reaction centers and electron transfer mechanisms in purple bacteria and AAnP bacteria, it is presently not completely understood what is the rate limiting step for the process of aerobic anoxygenic photosynthesis. Oxidative stress may be one of the key problems limiting the extent to which anoxygenic photosynthesis is feasible in an aerobic cell environment. Another might be the electrochemical potential of intermediate electron carriers in the photosynthetic membrane complex. Solving this problem might contribute towards a deeper understanding of the evolution of oxygenic photosynthesis.

\section{Adaptive advantage of aerobic anoxygenic photosynthesis}

The contribution of aerobic anoxygenic photosynthesis towards biomass yield has been most clearly demonstrated by chemostat cultures grown in regular diurnal day/night cycle (113; Biebl unpublished). Bchla is only synthesized during the night, its decrease during the day being consistent with dilution by growth in the absence of synthesis. Protein concentration increases during the day, and its concentration is always higher under day/night illumination cycles than in constant darkness (or constant light). These data could mean that the energy generation by bchla, which provides the cell with ATP for active transport, nutrient uptake, movement, and biosynthesis, has to be balanced against oxidative stress by bchla, which is strongest during the day. Thus, bchla driven photophorphorylation has to be maintained at a low level, but has an adaptive advantage in the ocean under stable light conditions and nutrient limitation, since every ATP molecule generated by photophosphorylation reduces the need for organic carbon compounds. It seems likely, however, that nutrient limitation and other factors important in the natural habitat 
need to be reproduced in the laboratory much more realistically to show this clearly.

Interesting parallels can be drawn by comparison with proteorhodopsin, a light driven proton pump which has been discovered to be highly expressed in the oligotrophic ubiquitous marine picoplankton bacterium Pelagibacter ubique SAR11, where it covers about $20 \%$ of the cell surface (29). However, no consistent increase in growth yield could be observed in the light(29). Thus, either the "right" conditions have not yet been found or it is not growth yield which is increased in the light, but other traits relevant in the ocean, e.g. longterm resistance against starvation (101).

\section{CARBON MONOXIDE OXIDATION}

Carbon monoxide $(\mathrm{CO})$ is one of the most important chemical reactants in the troposphere; it affects the fate of the greenhouse gases ozon and methane by removing the major atmospheric oxidizing agent, hydroxyl radical (80). CO is produced by natural and anthropogenic sources (burning of fossil fuels and biomass, oxidation of atmospheric hydrocarbons by sunlight, release from ocean and vegetation) which account for an emission of $12-14 \times 10^{8}$ tons CO per year (48). However, repeated measurements have shown that concentrations of $\mathrm{CO}$ in the atmosphere are relatively constant, ranging from 0.06 to $0.15 \mathrm{ppm}$ (48), indicating that it is steadily consumed.

High concentrations of $\mathrm{CO}$ are extremely toxic for animals since $\mathrm{CO}$ binds irreversibly to the heme iron of hemoproteins, resulting in hypoxia and death (83). However, numerous bacteria can use $\mathrm{CO}$ as a source of carbon and energy. Carbon monoxide oxidation has been shown under both aerobic (64) and anaerobic conditions (e.g. $(95,96))$. However, most studies focused on a small number of bacteria which grow autotrophically on CO using external electron acceptors like sulfate or $\mathrm{CO}_{2}$. In the environment, however, bacteria may be more important which do not 
grow chemoautotrophically, but use $\mathrm{CO}$ at ambient concentrations to supplement their carbon and energy budget. It has been shown that aerobic root associated $\mathrm{CO}$ consumption by carboxydotrophic bacteria plays a large role in wetlands (80). Terrestrial microbes remove as much as 15 $\%$ of the annual flux of $\mathrm{CO}$ to the atmosphere, but the populations involved in situ are poorly known (19).

Two operons for CO oxidation were found in the genome of S. pomeroyi (69) which belonged to the two different coxL clusters BMS and OMP, respectively (53). Enzymes from the BMS cluster have been shown to have a relatively low affinity to $\mathrm{CO}$, while those in the OMP cluster have a higher affinity. The presence of both genes in the same organism indicates a possible adaptive advantage for optimal enzyme kinetics under a range of CO concentrations (53). The frequency of coxL genes in the environmental Sargasso Sea shotgun library was $7.1 \%$, while the Roseobacter lineage was represented at appr. $3 \%$ of all 16S rRNA genes (69). Thus, other marine phyla must also play a role for $\mathrm{CO}$ oxidation in the ocean.

Using PCR primers targeting the cox $L$ gene coding for carbon monoxide dehydrogenase, it became clear that the ability for $\mathrm{CO}$ oxidation is much more widely distributed than previously thought (53), being present in numerous species of Alphaproteobacteria, Betaproteobacteria, and Gammaproteobacteria, including Silicibacter pomeroyi (69), several clusters of the Roseobacter lineage (18) and the closely related marine Alphaproteobacterium genus Stappia. Further studies based on total DNA extracts from volcanic deposits suggested that it is also present in Actinobacteria, Firmicutes and novel organisms which have not yet been identified $(25,26)$.

While none of the Roseobacter organisms studied to date uses the Calvin cycle to synthesize biomass, anaplerotic $\mathrm{CO}_{2}$ fixation has been described during heterotrophic growth (113). $\mathrm{CO}$ oxidation may improve this process by providing an additional intracellular pool of $\mathrm{CO}_{2}$ to the microbes. Both aerobic $\mathrm{CO}$ oxidation and aerobic anoxygenic phototrophy, known previously as an autotrophic way of life restricted to rare and extreme habitats, are used as an additional mode 
of generating energy in the Roseobacter lineage. Interestingly, recently an Epsilonproteobacterium has been enriched from a North Sea sediment which can grow in an atmosphere of $100 \%$ $\mathrm{CO}$ or microaerobically and is able to couple the oxidation of carbon monoxide to the reduction of reduced sulfur compounds (49). Although the result of an enrichment procedure and thus probably not representative of natural microbial populations, this type of metabolism might be a model for Roseobacter metabolic networks which might also link $\mathrm{CO}$ oxidation and sulfur metabolism.

\section{ROLE OF THE ROSEOBACTER LINEAGE FOR SULPHUR CYCLING IN THE OCEAN}

At least 12 of the 41 major Roseobacter lineages are involved in sulfur transformation reactions (18). Most important from an ecological point of view is the degradation of the algal osmolyte demethylsulfoniopropionate (DMSP) through both the cleavage and the demethylation/dethiolation pathway, yielding the climate relevant gas dimethylsulfide (DMS) as well as carbon and sulfur compounds for incorporation into microbial biomass (Fig.3). In addition, sulfur-based lithoheterotrophy has been discovered in several Roseobacter strains $(98,99)$ and the genome of Silicibacter pomeroyi (69). Roseobacter strains are also involved in transformations of DMS (35), methanethiol, methanesulfonate (46), and DMSO (70).

\section{Source and biogeochemical importance of DMSP and DMS}

DMSP is a sulfonium compound produced as an osmoprotectant in high concentrations by marine micro- and macroalgae and halophytic plants from methionine (111). It is released into the ocean water by leakage, death, or grazing, and is probably one of the most important sulfur and carbon sources of marine bacteria. One of its degradation products is the volatile DMS, which is 
universally present in seawater and emitted at a significant rate to the atmosphere (61). It was identified as the missing gaseous compound needed to enable the steady state flow of sulfur between terrestrial and marine environments, making DMS emissions a key step in the global sulfur cycle and a shuttle between sea and land $(61,111)$. In the atmosphere, DMS is oxidised to acidic aerosol sulfates which serve as "cloud condensing nuclei" and absorb incoming radiation before falling to earth as acid rain (111). Model calculations have shown that a reduction in the amount of sunlight which reaches the earth's surface caused by a change in DMS concentration could theoretically decrease the global mean temperature $(110,111)$.

The total annual flux of biogenic DMS from the ocean has been estimated to be $13-37 \mathrm{Tg}(51$, 111), at least one order of magnitude higher than from all other sources, including soils and plants, salt marshes and freshwater swamps. This amount is even more remarkable since between $50 \%$ (111) and 85\% (115) of the released DSMP is demethylated, and a fraction of DMS is oxidized by bacteria in the water column before it reaches the atmosphere $(52,111)$.

\section{Degradation of DMSP}

Since DMSP is the main source or DMS, its degradation has been studied extensively. There are two principal degradation routes (70) (Fig. 3):

1. The "cleavage pathway" by a lyase enzyme to form DMS and acrylate, which is used by both eukaryotic algae and many bacteria.

2. The "demethylation/demethiolation pathway" which is only found in bacteria. It results in formation of MMPA (3-methyl-mercaptopropionate) plus a methyl compound. MMPA can be degraded further either by the "double demethylation pathway" to form MPA (3mercaptopropionate) plus a methyl compound, or by demethiolation, resulting in methanethiol (MeSH) and acrylate. MeSH can be further metabolised to sulfide and sulfate or serves as precursor for the synthesis of the sulfur containing amino acid methionine, thus closing the circle. 
The two different routes of DMSP degradation have fundamentally different biogeochemical implications. The cleavage pathway results in DMS production, increases the formation of cloud condensing nuclei and counteracts the process of global warming, while the demethylation/dethiolation pathway results in uptake of both the carbon and sulfur containing moieties of DSMP into microbial cells and thus increases their residence time in biomass.

\section{Role of the Roseobacter lineage for DMSP degradation}

Roseobacter strains have been among the first aerobic bacteria isolated which are able to grow on DMSP $(34,35,59)$. They are the only bacteria known to have both the degradation and the demethylation/dethiolation pathway, sometimes within the same organism $(65,70)$. They exhibit a positive chemotactic response towards DMSP degradation products (66). The genome sequence of Silicibacter pomeroyi revealed no less than 5 uptake systems for glycine betaine and/or DMSP (OpuA and OpuD) (69). In such a way Roseobacter organisms are optimally adapted to algal blooms, where DMSP is released locally in large, varying quantities.

\section{Transformation of inorganic sulfur compounds}

Roseobacter strains have frequently been found to be able to transform sulfite and thiosulfate to sulfate under aerobic conditions. Sulfitobacter pontiacus, from the oxic/anoxic interface of the Black Sea (97) has a sulfite reductase activity which is almost as high as that of autotrophic inorganic sulfur reducers (35). While none is known to be able to grow lithoautotrophically, thiosulfate enhances the growth yield of many strains, sometimes by $45 \%$ (69) again confirming that these bacteria use all energy sources which are available to them, without being specialized to a single on. Accordingly, sox genes have been found in the genome of Silicibacter pomeroyi (69) and also with a high prevalence $(10 \%)$ in the Sargasso Sea metagenome library $(10 \%,(69))$. In the marine environment, reduced sulfur compounds can occur either at the interface between aerobic and anaerobic environments in stratified ecosystems (e.g. in the Black Sea), in anaerobic microniches (e.g. biofilms on planktonic invertebrates or marine snow particles), or they can be 
the products of DMSP degradation.

\section{EUKARYOTIC HOSTS: MUTUALISM, SYMBIOSIS AND PATHOGENE-} SIS

Symbiotic relationships between bacteria and eukaryotic hosts are a fascinating chapter of natural products biochemistry. For example, the most promising drug from the sea, bryostatin, was isolated from the bryozoan Bugula neritica and is currently in phase II clinical trials for a several cancer types. It is a polyketide which has been clearly shown to be produced by the as yet uncultured symbiont "Candidatus Endobugula sertula" (reviewed by $(40,73)$ ).

Roseobacter strains have been found in close association with diverse marine Eukaryotes, eg. marine red and green macroalgae, marsh grass, diatoms, bryozoa, corals, oysters, squid, and dinoflagellates. They are the dominant microorganisms in the reproductive glands of certain cephalopods and the phycosphere of Pfiesteria dinoflagellates. In many of these associations the precise nature of the interaction has not been determined. In some cases, evidence has been found for a coevolution between host and microorganism (5).

\section{Dinoflagellate toxins}

More than 4000 living and fossile species of dinoflagellates are presently known. Only about 25 of these produce polyketide toxins of large structural complexity (79). The largest non-peptidic, non-polymeric natural product described to date, maitotoxin, is produced by the dinoflagellate Gymnodinium toxicus, and the only natural products possessing five, six, seven, eight and nine membered rings in the same molecule are the polyethers brevetoxin A and ciguatoxin, produced by the dinoflagellates Gymnodinium breve and G. toxicus, respectively (79). These toxins are highly potent sodium channel blockers (79). 
Dinoflagellates are responsible for alga blooms known as red tides. Food chain accumulation of their toxins was identified as the reason for paralytic shellfish poisoning and fish kills (27). It was further suggested that the associated bacteria might be the true producers of the toxins rather than the algae $(54,90)$. Dinoflagellates live in close association with intracellular and extracellular bacteria, which can be found in all life stages of the alga in the nucleus, the cytoplasma and on the cell surface.

Intitially, Kodama et. al. reported that after curing cultures of Protogonyaulax (later renamed as Alexandrium) tamarense from bacteria using antibiotics, intracellular bacteria could be obtained by breaking the cells, and these were shown to produce small amounts of saxitoxins (paralytic shellfish toxins) (54). The bacteria, first named Moraxella sp., were later identified as strains belonging to the Roseobacter lineage $(38,57,76)$. Silva et al. (90) isolated an intracellular bacterium from A. tamarense which, when inoculated into non-toxic algal cultures of other dinoflagellates, induced toxin production and concluded that the bacteria, which were not toxic in pure culture, caused the toxicity of the algae by interfering with algal metabolism. Gallacher et al. initially described that $40-60 \%$ of the bacterial isolates from cultures of toxic Alexandrium spp. produced paralytic shellfish toxin (saxitoxin) in very high concentrations (28). Many of these bacteria belonged to the Roseobacter lineage (44).

These initial findings could not be confirmed by other authors (22). Lu and coworkers isolated both intra- and extracellular bacteria from the toxic dinoflagellate Alexandrium minutum $\mathrm{T} 1$ and found that none of them produced toxins, and the toxicity of the dinoflagellate culture was even higher in the absence of bacteria (62). Other groups also observed that the dinoflagellates produced the same or only slightly changed toxins if cultured axenically $(104,109)$. Gallachers group later showed that two toxin producing strains of dinoflagellates (Alexandrium lusitanicum and A. tamarense) exhibited the same toxin profile with and without bacteria (43). Martins et al. demonstrated that earlier results regarding toxin producing Pseudomonas strains were false posi- 
tives caused by cellular and medium components in the raw extracts (63).

In 2005, the polyketide origin of most dinoflagellate toxins and their biochemical synthesis had been firmly established by feeding experiments and are reviewed by Moore (68). The ability for toxin production was shown to be inherited in a Mendelian way, indicating that it is located with the dinoflagellate rather than the associated bacteria. Moreover, the presence of type I polyketide synthases (PKS) has been demonstrated in toxin producing dinoflagellates (the okadaic acid producers Prorocentrum lima and P. hoffmanianum; Karenia brevis (formerly Gymnodinium breve), a producer of brevetoxin, Amphidinium operculatum and several others), while no type II PKS, characteristic of bacteria, were detected $(93,94)$. However, some doubts are still remaining. It could not be excluded that at least some of the identified PKS genes might originate from the accompanying bacteria, and the amplified and sequenced fragments were so small, that their phylogenetic affiliation could not clearly be established $(93,94)$. Studies on whole genome gene expression profiling in $K$. brevis should finally clarify this question in the near future (60). For the time being, it has to be summarized that no toxin producing bacterial strain has been isolated from a dinoflagellate so far, and there is strong evidence that the associated bacteria do not produce toxins, but may be involved in other interactions with the host.

\section{Mutualistic interactions between Roseobacter strains and marine algae}

Roseobacter organisms can represent a large percentage of the associated bacteria of planktonic algae and dinoflagellates in particular. For example, Alavi and coworkers (1) showed that $50 \%$ of the clones obtained from Pfiesteria culture medium belonged into the Roseobacter lineage, and FISH and CFLSM studies showed bacteria in close association with the cell surface and within the Pfiesteria cells. Several types of interactions have been suggested:

(1) Degradation of the algal osmolyte DMSP. Roseobacter strains associated with Pfiesteria

cultures are able to degrade DMSP, which reaches intracellular concentrations up to $500 \mu \mathrm{M}$ and is released upon cell death or aging $(65,111)$. Moreover, chemotaxis of Roseobacter strains to- 
wards DMSP degradation products was demonstrated (65).

(2) Epibiosis to obtain both light and nutrients, required for AAnP bacteria. The large number of AAnPs which could be isolated from the surface of toxin producing Alexandrium sp. and Prorocentrum sp. $(3,10,12)$ may indicate that the dinoflagellates served as ferries transporting bacteria to depths sufficiently illuminated for photosynthesis and also provided locally high concentrations of DOM.

(3) Roseobacter strains have been shown to degrade or transform dinoflagellate toxins (92), thus confirming earlier findings that in the presence of bacteria less toxin is produced (62).

(4) Production of algal-lytic compounds has been shown to occur in Roseobacter strains (4). In such a way, they might recruit large amounts of nutrients and affect the population dynamics of algal blooms.

(5) Alavi et al. (2) have revealed a very special relationship between a Roseobacter isolate living in association with the dinoflagellate Pfiesteria piscicida and its prey algae, Rhodomonas. For reasons which are not understood the presence of the Rosoebacter strain enhances the predation rate of the dinoflagellate on Rhodomonas, resulting in better growth.

Thus, Roseobacter strains might have an important role for controlling toxicity and duration of algal blooms by the mechanisms listed above.

\section{Roseobacter pathogens}

Juvenile oyster disease (JOD) refers to a syndrome resulting in seasonal mortalities of hatchery produced juvenile Crassostrea virginica raised in the northeastern United States (13). Mortalities can be up to $90 \%$ of total production in some years. Infected animals are heavily colonized by Roseovarius crassostreae (14). Interestingly, an Alphaprotetobacterium from the alpha-2 subgroup, Stappia stellulata, is also able to colonize Crassostrea larvae and seems to prevent infection by Roseovarius crassostreae, thus having a probiotic effect (13). The same or a very similar 
strain of Roseovarius was also found associated with two diseases of scleractinean corals in the Caribbean, e.g. white plague (72) and black band disease (20).

\section{Roseobacter probiotics}

Aquaculture is very vulnerable to opportunistic pathogenic bacteria which may spread rapidly through the dense population, causing $>99 \%$ mortality. Rearing units for larvae of the turbot, a marine flatfish (Scophthalmus maximus) were used as sources for indigenous bacterial antagonists that might have the potential to be used as probiotic strains $(41,42)$. After screening 8500 colonies for antibacterial activity against the fish pathogens Vibrio anguillarum, $V$. splendidus and Pseudoalteromonas sp., 15 Roseobacter strains were found which were strongly inhibitory against all three pathogens and did not cause mortality in the turbot larvae (41). Strain 27-4 was $99.1 \%$ identical to Roseobacter gallaeciensis (81). Cell extracts of $R$. gallaeciensis had already been used earlier as a probiotic to increase the survival of scallop larvae (82).

The natural abundance and diversity throughout the year of Roseobacter potential probiotics was then investigated in turbot rearing units by screening a total of 19000 colonies (from tank walls,

tank water, and larvae) for inhibition of the fish pathogen V. anguillarum (42). 132 antagonistic Roseobacter isolates were found, which fell into several phylogenetic cluster, including the previously isolated Roseobacter gallaeciensis related isolate 27-4 (42).

\section{PRODUCTION OF ANTIBIOTICS AND QUORUM SENSING}

\section{Antibiotics}

Two antibiotics have been isolated from Roseobacter strains: Tryptantrin from Oceanibulbus indolifex (107) and thiotropocin from the Roseobacter gallaeciensis related isolates T5 (15)and 27-4 (16). Interestingly, the production of thiotropocin was only found under static growth condi- 
tions, when the bacteria formed star shaped aggregates (16). Many Roseobacter strains are very good biofilm formers, and they were shown to be among the earliest colonizers of marine surfaces (21), where the production of an antibiotic might represent an important competitive advantage. Thiotropocin is a sulfur containing antibiotic and may be derived from the metabolism of DSMP. A number of sulfur containing indole derivatives and other secondary metabolites whose functions remain to be elucidated were also found in Roseobacter strains (107).

\section{Quorum sensing}

The synthesis of thiotropocin was correlated with cell density, indicative of quorum sensing regulation $(15,16)$. Indeed, C10-OH-HSL was identified in culture supernatants of strain 27-4 (16), an ayclated homoserine lactone (AHL) previously discovered in the plant pathogen Pseudomonas fluorescens and the human pathogen Burkholderia pseudomallei.

Production of AHLs has been detected in many lineages of the Roseobacter lineage $(37,108)$. Functional LuxI and LuxR homologues were found in the genome of Silicibacter pomeroyi (69). Roseobacter strains typically produce mixtures of AHLs with chain lengths from 8 to 18 carbon atoms and one or two unsaturations; some of these compounds are new, some are similar to those of the Rhizobiales, a group of symbiotic soil bacteria also belonging to the Alphaproteobacteria (108). Regulation of gene expression in relation to cell density can be expected to be most important if the bacteria live in close proximity in confined spaces, e.g. as intracellular bacteria, within body cavities of the host, or in biofilms on surfaces of suspended particles, dinoflagellates, marine invertebrates or macroalgae, all modes of life which are very common for Roseobacter organisms. Traits known to be regulated by quorum sensing are host-symbiont and host-pathogen interactions, the production of polysaccharides, gene transfer, formation of biofilms, and production of antibiotics and toxins, in other words, most of the specific adaptations of the organisms to their respective habitat and lifestyle with the exception of primary energy yielding metabolism. Moreover, AHLs may be involved in the regulation of culturability (17). The Roseobacter group 
is exploiting many diverse ecological niches and has a relatively large genome $(69,75)$, rather than being exclusively adapted to the oligotrophic ocean like SAR11, whose streamlined genome does not contain any signs of quorum sensing related signalling (32). Thus, complex regulatory mechanisms can be expected.

Cyclic dipeptides (diketopiperazines) were repeatedly isolated from Roseobacter isolates (67, 107). Their biological role is not yet clear; while some have been reported to act a quorum quenching compounds in high concentrations (45), most seem to be remains of the culture medium (108). No luxS homologues have been found until now in the genomes of Alphaproteobacteria $(100,105)$, indicating that autoinducer-2 related signalling is absent or restricted to the "listening" component in these organisms.

\section{GENOMES AND METAGENOMES}

The genome sizes of Silicibacter pomeroyi and Roseobacter litoralis are 4.6 and $4.7 \mathrm{Mp}$, respectively, including extrachromosomal elements $(69,75)$. They are typical for free living bacteria with a versatile mode of life. At the moment, only the genome of Silicibacter pomeroyi has been fully sequenced (69) and revealed a number of adaptations to the marine environment, including the carbon monoxide oxidation pathway, the ability to reduce inorganic sulfur compounds, two AHL synthases, and the multitude of $\mathrm{ABC}$ transporter systems.

Extrachromosomal elements are common in Roseobacter organisms. Large circular megaplasmids, linear plasmids and small circular plasmids have all been found in phototrophic Roseobacter strains (75). For example, Dinoroseobacter shibae harbors no less than 7 linear plasmids, together comprising $860 \mathrm{kbp}$ of genetic information (75). Plasmids are, however, not restricted to phototrophs: S. pomeroyi has a megaplasmid of $591 \mathrm{kbp}$ length (69). Two large cryptic plasmids have been found in a Ruegeria strain (114). All linear plasmids known today are conjugative, 
thus horizontal gene transfer can be expected to play a large role in shuffling adaptive information between Roseobacter populations. Theoretically, some of the linear plasmids could also represent lysogenic phages at a certain point in their life cycle, thus opening up additional routes for gene transfer and population control.

Cultivation independent information beyond the $16 \mathrm{~S}$ rRNA sequence is accumulating at a fast rate. Large insert bacterial artificial chromosome (BAC) and fosmid libraries allow to clone genome fragments up to $200 \mathrm{~kb}$, theoretically representing $5-10 \%$ of a small bacterial genome (23). They have been screened for biochemical traits coupled to 16S rRNA phylogenetic tags and lead to the discovery of proteorhodopsin phototrophy in the sea $(7,8,84)$. Shotgun libraries of total community DNA are also beginning to be available, starting with the Sargasso Sea metagenome library (106), which represents an inventory of 1.2 million pooled microbial genes without the bias of PCR amplification (31). It is expected that similar inventories will become available from practically all marine habitats in the upper zone of the ocean in the near future. The Sargasso Sea, an extreme and very oligotrophic environment, has always been regarded as a habitat with a low diversity of microbes. However, from the shotgun library 1500 different species were estimated to be present (106), which made it impossible to assemble reasonable amounts of genomic DNA reliably (23). Thus, genome sequences of ecologically abundant marine bacteria are urgently needed as a reference (http://www.moore.org/).

\section{SUMMARY AND OUTLOOK}

Marine microbiology, always at the forefront of microbial ecology, is advancing at a breathtaking rate through sequencing of whole genomes of ecologically important cultivated strains, metagenome analyses and the ecological, physiological and genetic experiments which are being based on these data. The Roseobacter group is abundant in diverse marine habitats and involved in 
global biogeochemical cycles (e.g. sulfur and carbon cycle) and interactions with marine plants and animals, with important implications for marine ecology and the global climate. It is unique since cultivated and not yet cultivated organisms are closely related and a mosaic of physiological traits is present at the subspecies level. Over the next two years, about 40 full genome sequences will become available for the Roseobacter group, more than for any other lineage of microbes of environmental importance. Many of the sequenced strains are representative of ecologically important Roseobacter lineages and will be subjected to the powerful methods of functional genomics investigations. On this basis it should be possible to elucidate the specific adaptations of Roseobacter organisms to their respective ecological niches in the ocean and understand the mechanisms controlling culturability in this important marine lineage. 


\section{FIGURE LEGENDS}

Fig. 1. The 41 major clusters of the Roseobacter lineage. The tree includes all currently described genera and the 13 major clusters described in the text. Filled triangles represent clusters of $\geq 10$ nonredundant members, and unfilled triangles represent clusters with $<10$ members. Described strains within each cluster are shown in parentheses. Robust phylogenetic lineages are indicated with filled ovals at branch nodes and vertical black lines. Numbers of clone and isolate sequences representing each cluster are provided in brackets ([number of clones:number of isolates]). Colored symbols represent evidence for the indicated physiologies. The tree is based on the sequences listed in (18). S. meliloti (D14509) served as the outgroup. The tree is based on positions 92 to 1443 of the 16S rRNA gene (E. coli numbering system). Prior to analysis, a filter was applied to the aligned sequences to exclude positions with $<50 \%$ conservation. The tree was constructed using Phylip and the neighbor-joining method. The bar represents Jukes-Cantor evolutionary distance. Bootstrap values of $>50 \%$ are shown at branch nodes (100 iterations). From (18), with permission.

Fig. 2. Scheme of the arrangement of protein complexes in the photosynthetic membrane of anoxygenic bacteria and the flow of electrons during cyclic photophorphorylation. Light transforms the reaction center bchla (P870) into a strong electron donor. Electrons flow via the primary electron acceptor, $\mathrm{Q}_{\mathrm{A}}$, into the quinone pool, to the cytochrome $\mathrm{bc}_{1}$ complex and are transported back to $\mathrm{P} 870$ by the soluble cytochrome $\mathrm{c}_{2}$. In the process, a proton gradient is established across the cell membrane. By the ATPase membrane complex, ADP is phosphorylated to ATP at the expense of proton motive force. LH, light-harvesting complex consisting of carotenoids, bacteriochlorophyll and proteins (also called antenna complex); P870, reaction center with the special pair of bacteriochlorophyll molecules engaged in the primary electron transfer event, and the pufL and pufM proteins which determine its exact stereochemistry; Q, quinone; bc $_{1}$ cytochrome 
bc $_{1}$ complex; $c_{2}$, cytochrome $c_{2}$. Based on Brock: Biology of Microorganisms. $9^{\text {th }}$ edition by Michael T. Madigan, John M. Martinko and Jack Parker, 2000, Prentice-Hall Inc., Upper Saddle River, New Jersey 07458.

Fig. 3. Role of Roseobacter lineage bacteria for the global sulfur cycle. DMS, dimethylsulfide; DMSP, dimethylsulfoniopropionate; CCN, cloud condensing nuclei; MMPA, 3methylpropionate; MeSH, methanethiol; $\mathrm{X}-\mathrm{CH}_{3}$, unidentified molecule with a terminal methyl group; MPA, 3-mercaptopropionate; $\beta$-HP $\beta$-hydrocypropionate; DMSO, dimethyl sulfoxide. Based on (70) and (111) and references in these papers. The two pathways present in Roseobacter organisms are colored blue (demethylation/dethiolation pathway) and orange (cleavage pathway). See text for further explanation. 


\section{MINI GLOSSARY}

- anaplerotic metabolism: replenishment of tricarboxylic acid cycle intermediates during growth. The most important reactions are carboxylation of pyruvate or phosphoenolpyruvate to yield oxalacetate which acts as a precursor for biosynthetic reactions.

- autoinducer-2: furanosyl-borate-diester synthesized by the widely distributed $\operatorname{lux} S$ gene encoded autoinducer-2 synthase and potentially acting as a universal bacterial signalling molecule

- bacteriochlorophyll a: photosynthetic pigment used by bacteria

- carboxydotrophic: able to gain energy from the oxidation of carbon monoxide

- metagenome: total genomic content of all organisms in an environmental sample, extracted as total DNA and cloned into various types of vectors

- polyketide synthase: enzyme complex which adds acetate moieties to the growing carbon backbone of natural compounds of the polyketide type

- proteorhodopsin: membrane bound pigment able to transform light energy into a proton motive force across the membrane

- quorum sensing: density dependent regulation of gene expression in bacteria by small chemical signalling molecules called autoinducers

- rubisco: ribulose bisphosphate carboxylase, key enzyme of the Calvin cycle, the series of reactions by which most photosynthetic organisms convert $\mathrm{CO}_{2}$ to organic molecules

- shotgun clone library: total DNA from an organism or a microbial community is digested into small fragments (appr. $1.5 \mathrm{kpb}$ ), cloned into a standard cloning vector, and assembled after sequencing with high coverage using specially developed software. 


\section{ACRONYMS}

AAnP aerobic anoxygenic photosynthesis

AHL acylated homoserine lactone

AnAnP anaerobic anoxygenic photosynthesis

BAC bacterial artificial chromosome

bchla bacteriochlorophyll a

CFLSM confocal fluorescence laser scanning microscope

CO carbon monoxide

$\mathrm{CO}_{2} \quad$ carbon dioxide

DMS dimethylsulfide

DMSO dimethyl sulfoxide

DMSP dimethylsulfoniopropionate

FISH fluorescent in situ hybridisation

JOD juvenile oyster disease

LH light harvesting complex

LuxS autoinducer-2 synthase

MMPA 3-methylpropionate

MeSH methanethiol

MPA 3-mercaptopropionate

PKS polyketide synthase

pufL L-protein of the photosynthesis reaction center 
pufM M-protein of the photosynthesis reaction center

RC reaction center 


\section{SUMMARY LIST}

1. The Roseobacter lineage is a phylogenetically coherent group of marine Alphaproteobacteria. About 1500 16S rRNA gene sequences are available in public databases, which form 41 subcluster with similarities $\geq 99 \%$. Cultivated representatives of the group are closely related to not yet cultivated clones.

2. The Roseobacter lineage is one of the most abundant marine groups. Its abundance in sea water is highest in coastal zones and polar oceans (up to $25 \%$ of the total microbial community). Representatives have been found in all major marine habitats investigated. They are often associated with algal blooms, form biofilms on marine surfaces, and are known as symbionts and pathogens of marine invertebrates.

3. Aerobic anoxygenic photosynthesis (AAnP), a way of generating additional metabolic energy through the transformation of light energy into ATP, is present in many members of the group and thought to play a large role for the marine carbon cycle. It may represent an adaptation to diurnal light regimes in an oligotrophic environment.

4. $\mathrm{CO}$ is an important greenhouse gas which is present in the ocean at low concentrations. It is oxidised by Roseobacter strains as a way of gaining additional energy, thus reducing the emission of $\mathrm{CO}$ to the atmosphere.

5. The degradation of the algal osmolyte dimethylsulfoniopropionate (DMSP) through both the cleavage and the demethylation/dethiolation pathway are prominent features of the Roseobacter group and one of the reasons for their close association with algal blooms, affecting the global production of the climate relevant gas dimethylsulfide (DMS). They are also involved in numerous other sulfur transformation reactions, including oxidation of inorganic sulfur compounds.

6. Antibiotics and other bioactive secondary metabolites are produced by some Roseobacter 
strains; they may be involved in the probiotic and pathogenic effects observed.

7. Members of the Roseobacter lineage have a complex genome structure. Megaplasmids and linear plasmids are often found, which facilitate horizontal gene transfer and the adaptations of the organisms to their ecological niches.

8. Mixtures of longchain AHLs are produced by many species of the Roseobacter lineage, indicative of intra- and possibly interspecific cell-cell communication; they regulate the production of antibiotics and the biofilm mode of growth. 


\section{UNRESOLVED ISSUES AND FUTURE DIRECTIONS}

1. Culturability: At present, many different reasons for the observed unculturability of the majority of environmental bacteria are being discussed, from the "viable but not culturable state" induced by starvation, to the fact that types and concentrations of carbon, sulfur, and nitrogen sources and the incubation conditions for bacteria in the laboratory (either high or no oxygen and light, vigorous shaking, high temperature) are very artificial. The analysis of cultivated strains within most of the subclusters of the Roseobacter lineage should allow to develop concepts for the cultivation of the $60 \%$ presently not yet cultivated diversity within this lineage.

2. Metabolic networks and their control: Roseobacter strains combine several ways of generating energy, e.g. AAnP, sulfide and carbon monoxide oxidation, degradation of DMSP. Based on fully sequenced genomes, analyses of the cell proteome and transcriptome at ecologically relevant conditions will reveal metabolic networks of connected pathways and the role of quorum sensing control of gene expression. In such a way, the mechanisms controlling the contribution of the Roseobacter lineage to the global carbon and sulfur cycle can be analysed.

3. Evolution: The upcoming large number of fully sequenced genomes in the Roseobacter lineage will allow to study the adaptive radiation and evolution of this group far beyond the $16 \mathrm{~S}$ rRNA gene based phylogeny. Longterm evolution should be reflected in the phylogeny of conserved core genes of the Alphaproteobacteria, and shortterm adaptive radiation into ecotypes might be based on adaptive islands which are shuffled between its members through horizontal gene transfer. 


\section{BRIEF ANNOTATIONS OF 10 REFERENCES}

Only publications which are directly relevant to the Roseobacter lineage are annotated; major breakthroughs in related areas are cited in the text but not annotated here.

1. Beja O, Suzuki MT, Heidelberg JF, Nelson WC, Preston CM, Hamada T, Eisen JA, Fraser CM, DeLong EF. 2002. Unsuspected diversity among marine aerobic anoxygenic phototrophs. Nature 415:630-3 :

Discovered a large diversity of the pufLM genes of the photosynthesis reaction center in uncultivated marine Alphaproteobacteria and Betaproteobacteria.

2. Bruhn JB, Nielsen KF, Hjelm M, Hansen M, Bresciani J, Schulz S, Gram L. 2005. Ecology, inhibitory activity, and morphogenesis of a marine antagonistic bacterium belonging to the Roseobacter clade. Appl. Environ. Microbiol. 71:7263-70:

Showed that production of antibiotics in a Roseobacter isolate is quorum sensing controlled and coupled to biofilm growth.

3. Gonzalez JM, Simo R, Massana R, Covert JS, Casamayor EO, Pedros-Alio C, Moran MA. 2000. Bacterial community structure associated with a dimethylsulfoniopropionateproducing North Atlantic algal bloom. Appl. Environ. Microbiol. 66:4237-46 :

Quantified for the first time the abundance of the Roseobacter lineage during a DMSP producing algal bloom. 
4. King GM. 2003. Molecular and culture-based analyses of aerobic carbon monoxide oxidizer diversity. Appl Environ. Microbiol. 69:7257-65

Expanded the diversity of aerobic carbon monoxide oxidisers significantly.

5. Martins CA, Alvito P, Tavares MJ, Pereira P, Doucette G, Franca S. 2003. Reevaluation of production of paralytic shellfish toxin by bacteria associated with dinoflagellates of the Portuguese coast. Appl. Environ. Microbiol. 69:5693-8

Demonstrated that components in raw bacterial cell extracts other than paralytic shellfish toxins caused false positive results in toxicity and HPLC analyses.

6. Giovannoni SJ, Bibbs L, Cho JC, Stapels MD, Desiderio R, Vergin KL, Rappe MS, Laney S, Wilhelm LJ, Tripp HJ, Mathur EJ, Barofsky DF. 2005. Proteorhodopsin in the ubiquitous marine bacterium SAR11. Nature 438:82-5

Showed very high expression of proteorhodopsin in SAR11 without improved growth yield.

7. Moran MA, Buchan A, Gonzalez JM, Heidelberg JF, Whitman WB, Kiene RP, Henriksen JR, King GM, Belas R, Fuqua C, Brinkac L, Lewis M, Johri S, Weaver B, Pai G, Eisen JA, Rahe E, Sheldon WM, Ye W, Miller TR, Carlton J, Rasko DA, Paulsen IT, Ren Q, Daugherty SC, Deboy RT, Dodson RJ, Durkin AS, Madupu R, Nelson WC, Sullivan SA, Rosovitz MJ, Haft DH, Selengut J, Ward N. 2004. Genome sequence of Silicibacter pomeroyi reveals adaptations to the marine environment. Nature 432:910-3

First fully sequenced species from the Roseobacter lineage revealing numerous interesting adaptations. 
8. Pradella S, Allgaier M, Hoch C, Pauker O, Stackebrandt E, Wagner-Dobler I. 2004. Genome organization and localization of the pufLM genes of the photosynthesis reaction center in phylogenetically diverse marine Alphaproteobacteria. Appl. Environ. Microbiol. 70:3360-9

Found up to seven linear plasmids in phototrophic Roseobacter isolates by pulse field gel electrophoresis.

9. Kolber ZS, Van Dover CL, Niederman RA, Falkowski PG. 2000. Bacterial photosynthesis in surface waters of the open ocean. Nature 407:177-9

First in situ measurement of bchla concentrations in the ocean.

10. Selje N, Simon M, Brinkhoff T. 2004. A newly discovered Roseobacter cluster in temperate and polar oceans. Nature 427:445-8

The only oceanwide quantification of a Roseobacter subcluster, showing very high abundance in polar oceans. 


\section{SIDE BAR: QUORUM SENSING}

Many bacteria constantly secrete small, self produced signalling compounds (autoinducers) into the medium. These are sensed by neighbouring cells, and once a threshold concentration (the quorum) has been reached, induce or repress transcription through specific regulatory mechanisms. In such a way, expression of adaptive phenotypes is coordinated in the whole population in a density dependent way. This type of cell-cell-communication, also termed quorum sensing, was discovered in Vibrio fischeri, where it regulates the transition between the free living low density lifestyle and the high density symbiotic mode of life. Quorum sensing in Proteobacteria is mediated through acylated homoserine lactone (AHL) autoinducers, which are produced by a luxI type synthetase and regulate transcription through binding a luxR type regulatory protein. The length and modification of the acyl side chain determine the species specifity of the signalling mechanism. Most work on quorum sensing has focused on human pathogens, e.g. Pseudomonas aeruginosa, and very little is known about its role in environmentally important bacteria. AHLs discovered in the Roseobacter lineage have side chains from 8 to 18 carbon atoms length, the longest detected to date. They regulate biofilm formation and production of antibiotics and thus may play an important role for the transition between the planktonic and the biofilm mode of life. 


\section{LIST OF RELATED REVIEWS}

Buchan A, Gonzalez JM, Moran MA. 2005. Overview of the marine Roseobacter lineage. Appl. Environ. Microbiol. 71:5665-77

Giovannoni SJ, Stingl U. 2005. Molecular diversity and ecology of microbial plankton. Nature $437: 343-8$

DeLong EF, Karl DM. 2005. Genomic perspectives in microbial oceanography. Nature 437:33642

Gogarten JP and Townsend, JP. 2005. Horizontal gene transfer, genome innovation and evolution. Nat. Rev. Microb., published online 1 August 2005, doi:10.1038/nrmicro1204

Gevers D, Cohan FM, Lawrence JG, Spratt BG, Coeyne T, Feil E, Stackebrandt E, van de Peer Y, Vandamme P, Thompson FL and Swings J. 2005. Re-evaluating prokaryotic species. Nat. Rev. Microb. 3:733-9.

Arrigo K.2005. Marine microorganisms and global nutrient cycles. Nature 437:349-355. 


\section{LITERATURE CITED}

1. Alavi M, Miller T, Erlandson K, Schneider R, Belas R. 2001. Bacterial community associated with Pfiesteria-like dinoflagellate cultures. Environ. Microbiol. 3:380-96

2. Alavi MR. 2004. Predator/prey interaction between Pfiesteria piscicida and Rhodomonas mediated by a marine alpha proteobacterium. Microb. Ecol. 47:48-58

3. Allgaier M, Uphoff H, Felske A, Wagner-Dobler I. 2003. Aerobic anoxygenic photosynthesis in Roseobacter clade bacteria from diverse marine habitats. Appl. Environ. Microbiol. 69:5051-9

4. Amaro AM, Fuentes MS, Ogalde SR, Venegas JA, Suarez-Isla BA. 2005. Identification and characterization of potentially algal-lytic marine bacteria strongly associated with the toxic dinoflagellate Alexandrium catenella. J. Eukaryot. Microbiol. 52:191-200

5. Ashen JB, Goff LJ. 2000. Molecular and ecological evidence for species specificity and coevolution in a group of marine algal-bacterial symbioses. Appl. Environ. Microbiol. $66: 3024-30$

6. Beatty JT. 2002. On the natural selection and evolution of the aerobic phototrophic bacteria. Photosynth. Res. 73:109-14

7. Beja O, Aravind L, Koonin EV, Suzuki MT, Hadd A, Nguyen LP, Jovanovich SB, Gates CM, Feldman RA, Spudich JL, Spudich EN, DeLong EF. 2000. Bacterial rhodopsin: evidence for a new type of phototrophy in the sea. Science 289:1902-6 
8. Beja O, Spudich EN, Spudich JL, Leclerc M, DeLong EF. 2001. Proteorhodopsin phototrophy in the ocean. Nature 411:786-9

9. Beja O, Suzuki MT, Heidelberg JF, Nelson WC, Preston CM, Hamada T, Eisen JA, Fraser CM, DeLong EF. 2002. Unsuspected diversity among marine aerobic anoxygenic phototrophs. Nature 415:630-3

10. Biebl H, Allgaier M, Lunsdorf H, Pukall R, Tindall BJ, Wagner-Dobler I. 2005. Roseovarius mucosus sp. nov., a member of the Roseobacter clade with trace amounts of bacteriochlorophyll a. Int. J. Syst. Evol. Microbiol. 55:2377-83

11. Biebl H, Allgaier M, Tindall BJ, Koblizek M, Lunsdorf H, Pukall R, Wagner-Dobler I. 2005. Dinoroseobacter shibae gen. nov., sp. nov., a new aerobic phototrophic bacterium isolated from dinoflagellates. Int. J. Syst. Evol. Microbiol. 55:1089-96

12. Biebl H, Tindall BJ, Pukall R, Lünsdorf H, Allgaier M, Wagner-Dobler I. 2005. Hoeflea phototrophica, sp. nov., a marine aerobic Alphaproteobacterium that forms bacteriochlorophyll a. Int. J. Syst. Evol. Microbiol. published online 25 November 2005:

13. Boettcher KJ, Barber BJ, Singer JT. 2000. Additional evidence that juvenile oyster disease is caused by a member of the Roseobacter group and colonization of nonaffected animals by Stappia stellulata-like strains. Appl. Environ. Microbiol. 66:3924-30

14. Boettcher KJ, Geaghan KK, Maloy AP, Barber BJ. 2005. Roseovarius crassostreae sp. nov., a member of the Roseobacter clade and the apparent cause of juvenile oyster disease (JOD) in cultured Eastern oysters. Int. J. Syst. Evol. Microbiol. 55:1531-7 
15. Brinkhoff T, Bach G, Heidorn T, Liang L, Schlingloff A, Simon M. 2004. Antibiotic production by a Roseobacter clade-affiliated species from the German Wadden Sea and its antagonistic effects on indigenous isolates. Appl. Environ. Microbiol. 70:2560-5

16. Bruhn JB, Nielsen KF, Hjelm M, Hansen M, Bresciani J, Schulz S, Gram L. 2005. Ecology, inhibitory activity, and morphogenesis of a marine antagonistic bacterium belonging to the Roseobacter clade. Appl. Environ. Microbiol. 71:7263-70

17. Bruns A, Nubel U, Cypionka H, Overmann J. 2003. Effect of signal compounds and incubation conditions on the culturability of freshwater bacterioplankton. Appl Environ. Microbiol. 69:1980-9

18. Buchan A, Gonzalez JM, Moran MA. 2005. Overview of the marine Roseobacter lineage. Appl. Environ. Microbiol. 71:5665-77

19. Conrad R. 1996. Soil microorganisms as controllers of atmospheric trace gases (H2, CO, CH4, OCS, N2O, and NO). Microbiol Rev. 60:609-40

20. Cooney RP, Pantos O, Le Tissier MD, Barer MR, O'Donnell AG, Bythell JC. 2002. Characterization of the bacterial consortium associated with black band disease in coral using molecular microbiological techniques. Environ. Microbiol. 4:401-13

21. Dang H, Lovell CR. 2000. Bacterial primary colonization and early succession on surfaces in marine waters as determined by amplified rRNA gene restriction analysis and sequence analysis of 16S rRNA genes. Appl. Environ. Microbiol. 66:467-75 
22. Dantzer WR, Levin RE. 1997. Bacterial influence on the production of paralytic shellfish toxins by dinoflagellated algae. J. Appl. Microbiol. 83:464-9

23. DeLong EF. 2005. Microbial community genomics in the ocean. Nat. Rev. Microbiol. 3:459-69

24. DeLong EF, Karl DM. 2005. Genomic perspectives in microbial oceanography. Nature $437: 336-42$

25. Dunfield KE, King GM. 2004. Molecular analysis of carbon monoxide-oxidizing bacteria associated with recent Hawaiian volcanic deposits. Appl Environ. Microbiol. 70:4242-8

26. Dunfield KE, King GM. 2005. Analysis of the distribution and diversity in recent Hawaiian volcanic deposits of a putative carbon monoxide dehydrogenase large subunit gene. Environ. Microbiol. 7:1405-12

27. Flewelling LJ, Naar JP, Abbott JP, Baden DG, Barros NB, Bossart GD, Bottein MY, Hammond DG, Haubold EM, Heil CA, Henry MS, Jacocks HM, Leighfield TA, Pierce RH, Pitchford TD, Rommel SA, Scott PS, Steidinger KA, Truby EW, Van Dolah FM, Landsberg JH. 2005. Brevetoxicosis: red tides and marine mammal mortalities. Nature. $435: 755-6$

28. Gallacher S, Flynn KJ, Franco JM, Brueggemann EE, Hines HB. 1997. Evidence for production of paralytic shellfish toxins by bacteria associated with Alexandrium spp. (Dinophyta) in culture. Appl. Environ. Microbiol. 63:239-45 
29. Giovannoni SJ, Bibbs L, Cho JC, Stapels MD, Desiderio R, Vergin KL, Rappe MS, Laney S, Wilhelm LJ, Tripp HJ, Mathur EJ, Barofsky DF. 2005. Proteorhodopsin in the ubiquitous marine bacterium SAR11. Nature 438:82-5

30. Giovannoni SJ, Britschgi TB, Moyer CL, Field KG. 1990. Genetic diversity in Sargasso Sea bacterioplankton. Nature 345:60-3

31. Giovannoni SJ, Stingl U. 2005. Molecular diversity and ecology of microbial plankton. Nature 437:343-8

32. Giovannoni SJ, Tripp HJ, Givan S, Podar M, Vergin KL, Baptista D, Bibbs L, Eads J, Richardson TH, Noordewier M, Rappe MS, Short JM, Carrington JC, Mathur EJ. 2005. Genome streamlining in a cosmopolitan oceanic bacterium. Science 309:1242-5

33. Goericke R. 2002. Bacteriochlorophyll a in the ocean: Is anoxygenic bacterial photosynthesis important? Limnol. Oceanogr. 47:290-5

34. Gonzalez JM, Covert JS, Whitman WB, Henriksen JR, Mayer F, Scharf B, Schmitt R, Buchan A, Fuhrman JA, Kiene RP, Moran MA. 2003. Silicibacter pomeroyi sp. nov. and Roseovarius nubinhibens sp. nov., dimethylsulfoniopropionate-demethylating bacteria from marine environments. Int. J. Syst. Evol. Microbiol. 53:1261-9

35. Gonzalez JM, Kiene RP, Moran MA. 1999. Transformation of sulfur compounds by an abundant lineage of marine bacteria in the alpha-subclass of the class Proteobacteria. Appl. Environ. Microbiol. 65:3810-9 
36. Gonzalez JM, Simo R, Massana R, Covert JS, Casamayor EO, Pedros-Alio C, Moran MA. 2000. Bacterial community structure associated with a dimethylsulfoniopropionateproducing North Atlantic algal bloom. Appl. Environ. Microbiol. 66:4237-46

37. Gram L, Grossart HP, Schlingloff A, Kiorboe T. 2002. Possible quorum sensing in marine snow bacteria: production of acylated homoserine lactones by Roseobacter strains isolated from marine snow. Appl. Environ. Microbiol. 68:4111-6

38. Groben R, Doucette GJ, Kopp M, Kodama M, Amann R, Medlin LK. 2000. 16S rRNA Targeted Probes for the Identification of Bacterial Strains Isolated from Cultures of the Toxic Dinoflagellate Alexandrium tamarense. Microb. Ecol. 39:186-96

39. Henriques IS, Almeida AA, Cunha A, Correia A. 2004. Molecular sequence analysis of prokaryotic diversity in the middle and outer sections of the Portugese estuary Ria de Aveiro. FEMS Microbiol Ecol. 49:269-79

40. Hildebrand M, Waggoner LE, Lim GE, Sharp KH, Ridley CP, Haygood MG. 2004. Approaches to identify, clone, and express symbiont bioactive metabolite genes. Nat. Prod. Rep. 21:122-42

41. Hjelm M, Bergh O, Riaza A, Nielsen J, Melchiorsen J, Jensen S, Duncan H, Ahrens P, Birkbeck H, Gram L. 2004. Selection and identification of autochthonous potential probiotic bacteria from turbot larvae (Scophthalmus maximus) rearing units. Syst. Appl. Microbiol. 27:360-71 
42. Hjelm M, Riaza A, Formoso F, Melchiorsen J, Gram L. 2004. Seasonal incidence of autochthonous antagonistic Roseobacter spp. and Vibrionaceae strains in a turbot larva (Scophthalmus maximus) rearing system. Appl. Environ. Microbiol. 70:7288-94

43. Hold GL, Smith EA, Birkbeck TH, Gallacher S. 2001. Comparison of paralytic shellfish toxin (PST) production by the dinoflagellates Alexandrium lusitanicum NEPCC 253 and Alexandrium tamarense NEPCC 407 in the presence and absence of bacteria. FEMS Microbiol. Ecol. 36:223-34

44. Hold GL, Smith EA, Rappe MS, Maas E, Moore ERB, Stroempl C, Stephen JR, Prosser J, Birkbeck TH, Gallacher S. 2001. Characterisation of bacterial communities associated with toxic and non-toxic dinoflagellates: Alexandrium spp. and Scrippsiella trochoidea. FEMS Microbiol Ecol. 37:161-73

45. Holden MT, Ram CS, de Nys R, Stead P, Bainton NJ, Hill PJ, Manefield M, Kumar N, Labatte M, England D, Rice S, Givskov M, Salmond GP, Stewart GS, Bycroft BW, Kjelleberg S, Williams P. 1999. Quorum-sensing cross talk: isolation and chemical characterization of cyclic dipeptides from Pseudomonas aeruginosa and other gram-negative bacteria. Mol. Microbiol. 33:1254-66

46. Holmes AJ, Kelly DP, Baker SC, Thompson AS, De Marco P, Kenna EM, Murrell JC. 1997. Methylosulfonomonas methylovora gen. nov., sp. nov., and Marinosulfonomonas methylotropha gen. nov., sp. nov.: novel methylotrophs able to grow on methanesulfonic acid. Arch. Microbiol. 167:46-53 
47. Igarashi N, Harada J, Nagashima S, Matsuura K, Shimada K, Nagashima KV. 2001. Horizontal transfer of the photosynthesis gene cluster and operon rearrangement in purple bacteria. J. Mol. Evol. 52:333-41

48. IPPC. 2001. Climate Change 2001, The Scientific Basis. Contribution of Working Group 1 to the Third Assessment Report of the Intergovernmental Panel on Climate Change New York: Cambridge University Press.

49. Jensen A, Finster K. 2005. Isolation and characterization of Sulfurospirillum carboxydovorans sp. nov., a new microaerophilic carbon monoxide oxidizing epsilon Proteobacterium. Antonie Van Leeuwenhoek 87:339-53

50. Karl DM. 2002. Hidden in a sea of microbes. Nature. 415:590-1

51. Kettle AJ, Andreae MO. 2000. Flux of dimethylsulfide from the oceans: a comparison of updated data sets and flux models. J. Geophys. Res. 26:26793-808

52. Kiene RP. 1990. Dimethyl Sulfide Production from Dimethylsulfoniopropionate in Coastal Seawater Samples and Bacterial Cultures. Appl Environ. Microbiol. 56:3292-7

53. King GM. 2003. Molecular and culture-based analyses of aerobic carbon monoxide oxidizer diversity. Appl Environ. Microbiol. 69:7257-65

54. Kodama M, Ogata T, Sakamoto S, Sato S, Honda T, Miwatani T. 1990. Production of paralytic shellfish toxins by a bacterium Moraxella sp. isolated from Protogonyaulax tamarensis. Toxicon 28:707-14 
55. Kolber ZS, Plumley FG, Lang AS, Beatty JT, Blankenship RE, VanDover CL, Vetriani C, Koblizek M, Rathgeber C, Falkowski PG. 2001. Contribution of aerobic photoheterotrophic bacteria to the carbon cycle in the ocean. Science 292:2492-5

56. Kolber ZS, Van Dover CL, Niederman RA, Falkowski PG. 2000. Bacterial photosynthesis in surface waters of the open ocean. Nature 407:177-9

57. Kopp M, Doucette G, Kodama M, Gerdts G, Schütt C, Medlin LK. 1997. Phylogenetic analysis of selected toxic and non-toxic bacterial strains isolated from the toxic dinoflagellate Alexandrium tamarense. FEMS Microbiol Ecol. 24:251-7

58. Labrenz M, Collins MD, Lawson PA, Tindall BJ, Schumann P, Hirsch P. 1999. Roseovarius tolerans gen. nov., sp. nov., a budding bacterium with variable bacteriochlorophyll a production from hypersaline Ekho Lake. Int. J. Syst. Bacteriol. 49:137-47

59. Ledyard KM, DeLong EF, Dacey JWH. 1993. Characterization of a DMSP-degrading bacterial isolate from the Sargasso Sea. Arch. Microbiol. 160:312-8

60. Lidie KB, Ryan JC, Barbier M, Van Dolah FM. 2005. Gene expression in Florida red tide dinoflagellate Karenia brevis: analysis of an expressed sequence tag library and development of DNA microarray. Mar. Biotechnol. (NY). 7:481-93

61. Lovelock JE, Maggs RJ, Rasmussen RA. 1972. Atmospheric dimethyl sulfide and the natural sulfur cycle. Nature 237:452-3

62. Lu YH, Chai TJ, Hwang DF. 2000. Isolation of bacteria from toxic dinoflagellate Alexandrium minutum and their effects on algae toxicity. J. Nat. Toxins. 9:409-17 
63. Martins CA, Alvito P, Tavares MJ, Pereira P, Doucette G, Franca S. 2003. Reevaluation of production of paralytic shellfish toxin by bacteria associated with dinoflagellates of the Portuguese coast. Appl. Environ. Microbiol. 69:5693-8

64. Meyer O, Schlegel HG. 1983. Biology of aerobic carbon monoxide-oxidizing bacteria. Annu. Rev. Microbiol. 37:277-310.:277-310

65. Miller TR, Belas R. 2004. Dimethylsulfoniopropionate metabolism by Pfiesteriaassociated Roseobacter spp. Appl. Environ. Microbiol. 70:3383-91

66. Miller TR, Hnilicka K, Dziedzic A, Desplats P, Belas R. 2004. Chemotaxis of Silicibacter sp. strain TM1040 toward dinoflagellate products. Appl. Environ. Microbiol. 70:4692-701

67. Mitova M, Popov S, De Rosa S. 2004. Cyclic peptides from a Ruegeria strain of bacteria associated with the sponge Suberites domuncula. J Nat. Prod. 67:1178-81

68. Moore BS. 2005. Biosynthesis of marine natural products: microorganisms (Part A). Nat. Prod. Rep. 22:580-93

69. Moran MA, Buchan A, Gonzalez JM, Heidelberg JF, Whitman WB, Kiene RP, Henriksen JR, King GM, Belas R, Fuqua C, Brinkac L, Lewis M, Johri S, Weaver B, Pai G, Eisen JA, Rahe E, Sheldon WM, Ye W, Miller TR, Carlton J, Rasko DA, Paulsen IT, Ren Q, Daugherty SC, Deboy RT, Dodson RJ, Durkin AS, Madupu R, Nelson WC, Sullivan SA, Rosovitz MJ, Haft DH, Selengut J, Ward N. 2004. Genome sequence of Silicibacter pomeroyi reveals adaptations to the marine environment. Nature 432:910-3 
70. Moran MA, Gonzalez JM, Kiene RP. 2003. Linking a Bacterial Taxon to Sulfur Cycling in the Sea: Studies of the Marine Roseobacter Group. Geomicrobiol. J. 20:375-88

71. Nagashima KV, Hiraishi A, Shimada K, Matsuura K. 1997. Horizontal transfer of genes coding for the photosynthetic reaction centers of purple bacteria. J. Mol. Evol. 45:131-6

72. Pantos O, Cooney RP, Le Tissier MD, Barer MR, O'Donnell AG, Bythell JC. 2003. The bacterial ecology of a plague-like disease affecting the Caribbean coral Montastrea annularis. Environ. Microbiol. 5:370-82

73. Piel J. 2004. Metabolites from symbiotic bacteria. Nat. Prod. Rep. 21:519-38

74. Piel J, Hofer I, Hui D. 2004. Evidence for a symbiosis island involved in horizontal acquisition of pederin biosynthetic capabilities by the bacterial symbiont of Paederus fuscipes beetles. J Bacteriol. 186:1280-6

75. Pradella S, Allgaier M, Hoch C, Pauker O, Stackebrandt E, Wagner-Dobler I. 2004. Genome organization and localization of the pufLM genes of the photosynthesis reaction center in phylogenetically diverse marine Alphaproteobacteria. Appl. Environ. Microbiol. $70: 3360-9$

76. Prokic I, Brümmer F, Brigge T, Görtz H, Gerdts G, Schütt C, Elbrächter M, Müller WEG. 1998. Bacteria of the Genus Roseobacter Associated with the Toxic Dinoflagellate Prorocentrum lima. Protist 149:347-57 
77. Rappe MS, Vergin K, Giovannoni SJ. 2000. Phylogenetic comparisons of a coastal bacterioplankton community with its counterparts in open ocean and freshwater systems. FEMS Microbiol. Ecol. 33:219-32

78. Rathgeber C, Beatty JT, Yurkov V. 2004. Aerobic phototrophic bacteria: new evidence for the diversity, ecological importance and applied potential of this previously overlooked group. Photosynth. Res. 81:128

79. Rein KS, Borrone J. 1999. Polyketides from dinoflagellates: origins, pharmacology and biosynthesis. Comp Biochem. Physiol B Biochem. Mol. Biol. 124:117-31

80. Rich JJ, King GM. 1998. Carbon monoxide oxidation by bacteria associated with the roots of freshwater macrophytes. Appl Environ. Microbiol. 64:4939-43

81. Ruiz-Ponte C, Cilia V, Lambert C, Nicolas JL. 1998. Roseobacter gallaeciensis sp. nov., a new marine bacterium isolated from rearings and collectors of the scallop Pecten maximus. Int. J. Syst. Bacteriol. 48 Pt 2:537-42

82. Ruiz-Ponte C, Samain JF, Sanchez JL, Nicolas JL. 1999. The Benefit of a Roseobacter Species on the Survival of Scallop Larvae. Mar. Biotechnol. (NY) 1:52-9

83. Ryter SW, Otterbein LE. 2004. Carbon monoxide in biology and medicine. Bioessays. $26: 270-80$

84. Sabehi G, Loy A, Jung KH, Partha R, Spudich JL, Isaacson T, Hirschberg J, Wagner M, Beja O. 2005. New insights into metabolic properties of marine bacteria encoding proteorhodopsins. PLoS. Biol. 3:e273 
85. Schwalbach MS, Fuhrman JA. 2005. Wide-ranging abundances of aerobic anoxygenic phototrophic bacteria in the world ocean revealed by epifluorescence microscopy and quantitative PCR. Limnol. Oceanogr. 50:620-8

86. Selje N, Simon M, Brinkhoff T. 2004. A newly discovered Roseobacter cluster in temperate and polar oceans. Nature 427:445-8

87. Shiba T. 1991. Roseobacter litoralis gen. nov., sp. nov., and Roseobacter denitrificans sp. nov., aerobic pink-pigmented bacteria which contain bacteriochlorophyll a. Syst Appl Microbiol 14:140-5

88. Shiba T, Simidu U. 1982. Erythrobacter longus gen. nov., sp. nov., an aerobic bacterium which contains bacteriochlorophyll a. Int J Syst Bacteriol 32:211-7

89. Shiba T, Simidu U, Taga N. 1979. Distribution of Aerobic Bacteria Which Contain Bacteriochlorophyll a. Appl. Environ. Microbiol. 38:43-5

90. Silva ES. 1990. Intracellular bacteria: the origin of dinoflagellate toxicity. J. Environ. Pathol. Toxicol. Oncol. 10:124-8

91. Simu K, Hagstrom A. 2004. Oligotrophic bacterioplankton with a novel single-cell life strategy. Appl Environ. Microbiol. 70:2445-51

92. Smith EA, Grant F, Ferguson CM, Gallacher S. 2001. Biotransformations of paralytic shellfish toxins by bacteria isolated from bivalve molluscs. Appl. Environ. Microbiol. 67:2345-53 
93. Snyder RV, Gibbs PD, Palacios A, Abiy L, Dickey R, Lopez JV, Rein KS. 2003. Polyketide synthase genes from marine dinoflagellates. Mar. Biotechnol. (NY) 5:1-12

94. Snyder RV, Guerrero MA, Sinigalliano CD, Winshell J, Perez R, Lopez JV, Rein KS. 2005. Localization of polyketide synthase encoding genes to the toxic dinoflagellate Karenia brevis. Phytochemistry 66:1767-80

95. Sokolova TG, Kostrikina NA, Chernyh NA, Kolganova TV, Tourova TP, BonchOsmolovskaya EA. 2005. Thermincola carboxydiphila gen. nov., sp. nov., a novel anaerobic, carboxydotrophic, hydrogenogenic bacterium from a hot spring of the Lake Baikal area. Int J Syst Evol. Microbiol. 55:2069-73

96. Sokolova TG, Kostrikina NA, Chernyh NA, Tourova TP, Kolganova TV, BonchOsmolovskaya EA. 2002. Carboxydocella thermautotrophica gen. nov., sp. nov., a novel anaerobic, CO-utilizing thermophile from a Kamchatkan hot spring. Int J Syst Evol. Microbiol. 52:1961-7

97. Sorokin DY. 1993. Sulfitobacter pontiacus gen. nov., sp. nov. - a new heterotrophic bacterium from the Black Sea, specialized on sulfite oxidation. Microbiology 62:295-305

98. Sorokin DY, Kuenen JG. 2005. Haloalkaliphilic sulfur-oxidizing bacteria in soda lakes. FEMS Microbiol Rev. 29:685-702

99. Sorokin DY, Tourova TP, Spiridonova EM, Rainey FA, Muyzer G. 2005. Thioclava pacifica gen. nov., sp. nov., a novel facultatively autotrophic, marine, sulfur-oxidizing bacterium from a near-shore sulfidic hydrothermal area. Int J Syst Evol. Microbiol. $55: 1069-75$ 
100. Sun J, Daniel R, Wagner-Dobler I, Zeng AP. 2004. Is autoinducer-2 a universal signal for interspecies communication: a comparative genomic and phylogenetic analysis of the synthesis and signal transduction pathways. BMC. Evol. Biol. 4:36

101. Suyama T, Shigematsu T, Suzuki T, Tokiwa Y, Kanagawa T, Nagashima KV, Hanada S. 2002. Photosynthetic apparatus in Roseateles depolymerans 61A is transcriptionally induced by carbon limitation. Appl Environ. Microbiol. 68:1665-73

102. Suyama T, Shigematsu T, Takaichi S, Nodasaka Y, Fujikawa S, Hosoya H, Tokiwa Y, Kanagawa T, Hanada S. 1999. Roseateles depolymerans gen. nov., sp. nov., a new bacteriochlorophyll a-containing obligate aerobe belonging to the beta-subclass of the Proteobacteria. Int J Syst Bacteriol. 49 Pt 2:449-57.:449-57

103. Suzuki MT, Preston CM, Beja O, de IT, Jr., Steward GF, DeLong EF. 2004. Phylogenetic screening of ribosomal RNA gene-containing clones in Bacterial Artificial Chromosome (BAC) libraries from different depths in Monterey Bay. Microb. Ecol. 48:473-88

104. Uribe P, Espejo RT. 2003. Effect of associated bacteria on the growth and toxicity of $A l$ exandrium catenella. Appl. Environ. Microbiol. 69:659-62

105. Vendeville A, Winzer K, Heurlier K, Tang CM, Hardie KR. 2005. Making 'sense' of metabolism: autoinducer-2, LuxS and pathogenic bacteria. Nat. Rev. Microbiol. 3:383-96

106. Venter JC, Remington K, Heidelberg JF, Halpern AL, Rusch D, Eisen JA, Wu D, Paulsen I, Nelson KE, Nelson W, Fouts DE, Levy S, Knap AH, Lomas MW, Nealson K, White O, Peterson J, Hoffman J, Parsons R, Baden-Tillson H, Pfannkoch C, Rogers YH, Smith 
HO. 2004. Environmental genome shotgun sequencing of the Sargasso Sea. Science. 304:66-74

107. Wagner-Dobler I, Rheims H, Felske A, El Ghezal A, Flade-Schroder D, Laatsch H, Lang S, Pukall R, Tindall BJ. 2004. Oceanibulbus indolifex gen. nov., sp. nov., a North Sea alphaproteobacterium that produces bioactive metabolites. Int. J. Syst. Evol. Microbiol. 54:1177-84

108. Wagner-Dobler I, Thiel V, Eberl L, Allgaier M, Bodor A, Meyer S, Ebner S, Hennig A, Pukall R, Schulz S. 2005. Discovery of complex mixtures of novel long-chain quorum sensing signals in free-living and host-associated marine Alphaproteobacteria. Chembiochem 6:2195-206

109. Wang CH, Wang YY, Sun YY, Xie XT. 2003. Effect of antibiotic treatment on toxin production by Alexandrium tamarense. Biomed. Environ. Sci. 16:340-7

110. Wingenter OW, Haase KB, Strutton P, Friederich G, Meinardi S, Blake DR, Rowland FS. 2004. Changing concentrations of $\mathrm{CO}, \mathrm{CH}(4), \mathrm{C}(5) \mathrm{H}(8), \mathrm{CH}(3) \mathrm{Br}, \mathrm{CH}(3) \mathrm{I}$, and dimethyl sulfide during the Southern Ocean Iron Enrichment Experiments. Proc. Natl. Acad. Sci. U. S. A. 101:8537-41

111. Yoch DC. 2002. Dimethylsulfoniopropionate: its sources, role in the marine food web, and biological degradation to dimethylsulfide. Appl Environ. Microbiol. 68:5804-15

112. Yurkov V, Beatty JT. 1998. Isolation of Aerobic Anoxygenic Photosynthetic Bacteria from Black Smoker Plume Waters of the Juan de Fuca Ridge in the Pacific Ocean. Appl. Environ. Microbiol. 64:337-41 
113. Yurkov VV, Beatty JT. 1998. Aerobic anoxygenic phototrophic bacteria. Microbiol. Mol. Biol. Rev. 62:695-724

114. Zhong Z, Caspi R, Helinski D, Knauf V, Sykes S, O'Byrne C, Shea TP, Wilkinson JE, DeLoughery C, Toukdarian A. 2003. Nucleotide sequence based characterizations of two cryptic plasmids from the marine bacterium Ruegeria isolate PR1b. Plasmid. 49:233-52

115. Zubkov MV, Fuchs BM, Archer SD, Kiene RP, Amann R, Burkill PH. 2001. Linking the composition of bacterioplankton to rapid turnover of dissolved dimethylsulphoniopropionate in an algal bloom in the North Sea. Environ. Microbiol. 3:304-11 